\title{
Chasing the immortal strand: evidence for nature's way of protecting the breast genome
}

\author{
Nikolajs Zeps ${ }^{* 1}$ and Christine Hemmings ${ }^{2}$ \\ See related research by Bussard et al., http://breast-cancer-research.com/content/12/5/R86
}

\begin{abstract}
Mutations arise during cell division at a predictable rate. Besides DNA repair mechanisms, the existence of cellular hierarchies that originate with a stem cell serve to reduce the number of divisions necessary for normal physiology. In a previous issue, Bussard and colleagues demonstrate that mammary stem cells have an additional remarkable trait; namely the ability to selectively retain a template DNA strand during self renewal. In doing so, they avoid the accumulation of mutations in that so called 'immortal strand'. The implications of this are discussed with reference to the development and treatment of cancer.
\end{abstract}

It is often noted that fashion goes in cycles; keep those old clothes in the wardrobe long enough and they will enjoy a renaissance eventually! It seems that this is also true of many great ideas in science. In a previous issue, Bussard and colleagues [1] reacquaint us with John Cairns' immortal strand hypothesis, postulated some 35 years ago [2]. Cairns' hypothesis still remains relatively unknown to the majority of cancer researchers, perhaps in part due to the more esoteric nature of his proposal, and the difficulty of proving it.

Cairns published his hypothesis around the time that Knudson was popularizing Nordling's [3] concepts of multiple mutations being required for the genesis of cancer, through his own careful analysis of inherited retinoblastoma [4]. The notion of natural selection of cells carrying mutations that give a favourable survival advantage is now well established in cancer biology. However, Cairns recognized a problem with this concept: given the very large number of cell divisions in tissues

\footnotetext{
*Correspondence: nik.zeps@sjog.org.au

'St John of God Pathology, Level 5 Bendat Family Comprehensive Cancer Centre,

12 Salvado Road, Subiaco, WA 6008, Australia

Full list of author information is available at the end of the article
}

like the skin, gut and bone marrow, he thought it surprising that there should be as little cancer as there is, if mutations arise at the rate that was estimated to be the case. Why was this so?

Cairns focused his attention on the concept of adult stem cells that were understood to be responsible for the replenishment of rapidly dividing tissues, and to reside within cellular hierarchies in various tissues, such as the haematopoietic system. It was hypothesized that stem cells undergo asymmetric division, giving rise to two progeny: one destined to remain as an undifferentiated stem cell (self renewal) and one that could go on and divide again to give rise to progeny that expand in number and undergo differentiation. Various mechanisms whereby asymmetric division may occur have been elaborated in a recent review by Knoblich [5].

The concept of a cancer stem cell is also enjoying a resurgence, having essentially been proposed by Julius Cohnheim in 1867 [6] when he postulated that malignancies arise from 'embryonic rests'. Cairns reasoned that there may be less cancer than might be expected because stem cells divide less frequently and are fewer in number, but he went further by making the radical proposal that they also protect one of their DNA strands during semiconservative replication. That is, once a stem cell is formed, one of its DNA strands remains selectively segregated into a stem cell during division (as part of self renewal of that cell), reducing the likelihood of mutations accumulating in the stem cells during subsequent DNA replication.

This is not an easy concept and to some extent it is open to accusations of teleology. What Cairns needed was an experimental model, and he was ably helped in this regard by Chris Potten. Their initial DNA labelling experiment [7] provided experimental evidence for the hypothesis and has since inspired a great deal of research in this area. They demonstrated that intestinal epithelial cells in the mouse could be labelled with markers of DNA synthesis (such as tritiated thymidine, ${ }^{3} \mathrm{H}-\mathrm{TdR}$, or 5-bromodeoxyuridine, BrdU), and that cells retaining this label could be found in zones where stem cells were postulated to reside. More recently they have 
demonstrated that stem cells can be labelled in such a manner that they retain an initial label $\left({ }^{3} \mathrm{H}-\mathrm{TdR}\right)$ and may also take up another (BrdU) that is subsequently lost, proving that self renewing cells selectively segregate their template strands [8]. This work is the inspiration behind the work of Bussard and colleagues here, in their mammary epithelial model.

In many ways, the mouse mammary gland is an ideal model for experimentation aimed at elucidating how stem cells function in vivo. Ken DeOme and colleagues [9] showed that the cleared mammary fat pad could be used as an in vivo 'growth chamber' and that small portions of mammary epithelium could regrow into functioning mammary glands when transplanted into the fad pad. This model has been used by numerous groups since and, incredibly, Shackleton and colleagues [10] have shown that a single cell (defined as Lin ${ }^{-}$CD29hi CD24+) can give rise to an entire functioning mammary gland.

In this paper, Bussard and her colleagues used an immortalized premalignant mammary epithelial cell line, COMMA-D1, to derive subpopulations with different properties. Using these cells transplanted in the mammary fat pad model, they demonstrate that there exist subsets of long-lived label-retaining epithelial cells (LRECs) that can divide asymmetrically and retain their labelled strand. Their progeny can differentiate to form ductal or lobular structures and expand and differentiate in response to pregnancy. These cells may also take up a new label (BrdU) that is lost with subsequent divisions, just as Potten and colleagues [8] observed in intestinal cells.

These findings lend further support for Cairns' hypothesis, but more significantly by their use of a premalignant cell line emphasise the importance of the cancer stem cell concept. The clinical implications of this hypothesis have been well recognized: many current cytotoxic therapies (including radiotherapy and many conventional chemotherapeutic agents, such as spindle poisons) are based on killing rapidly dividing cells. That we may be targeting the wrong population, or not measuring our success appropriately, has been well reviewed $[11,12]$. Bussard and colleagues provide a timely reminder that we are still some way off targeting cancer stem cells, even some 35 years after Cairns published his revolutionary idea. That we are getting closer to understanding the nature of these stem cells provides hope that strategies aimed at identifying them in human cancer, and targeting them, are a step closer to reality.

\section{Abbreviations}

BrdU, 5-bromodeoxyuridine; ${ }^{3} \mathrm{H}-\mathrm{TdR}$, tritiated thymidine.

\section{Competing interests}

The authors declare that they have no competing interests.

\section{Author details}

'St John of God Pathology, Level 5 Bendat Family Comprehensive Cancer Centre, 12 Salvado Road, Subiaco, WA 6008, Australia. ${ }^{2}$ ACT Pathology at The Canberra Hospital, PO Box 11, Woden, ACT 2606, Australia.

Published: 17 January 2011

\section{References}

1. Bussard KM, Boulanger CA, Kittrell FS, Behbod F, Medina D, Smith GH: Immortalized, premalignant epithelial cell populations contain long-lived, label-retaining cells that asymmetrically divide and retain their template DNA. Breast Cancer Res 2010, 12:R86.

2. Cairns J: Mutation selection and the natural history of cancer. Nature 1975, 255:197-200

3. Nordling C: A new theory on cancer-inducing mechanism. Br J Cancer 1953, 7:68-72.

4. Knudson A: Mutation and cancer: statistical study of retinoblastoma. Proc Natl Acad Sci USA 1971, 68:820-823.

5. Knoblich J: Asymmetric cell division: recent developments and their implications for tumour biology. Mol Cell Biol 2010, 11:849-860.

6. Cohnheim J: Ueber entzundung und eiterung. Path Anat Physiol Klin Med 1867, 40:1-79.

7. Potten CS, Hume WJ, Reid P, Cairns J: The segregation of DNA in epithelial stem cells. Cell 1978, 15:899-906.

8. Potten CS, Owen G, Booth D: Intestinal stem cells protect their genome by selective segregation of template DNA strands. J Cell Sci 2002 115:2381-2388.

9. DeOme KB, Faulkin $\sqcup \mathrm{Jr}$, Bern HA, Blair PB: Development of mammary tumors from hyperplastic alveolar nodules transplanted into gland-free mammary fat pads of female C3H mice. Cancer Res 1959, 19:515-520.

10. Shackleton M, Vaillant F, Simpson KJ, Stingl J, Smyth GK, Asselin-Labat M-L, Wu L, Lindeman GJ, Visvader JE: Generation of a functional mammary gland from a single stem cell. Nature 2006, 439:84-88.

11. Hemmings $C$ : The elaboration of a critical framework for understanding cancer: the cancer stem cell hypothesis. Pathology 2010, 42:105-112.

12. Wicha MS Liu S, Gabriela Dontu G: Cancer stem cells: an old idea a paradigm shift. Cancer Res 2006, 66:1883-1890.

doi: $10.1186 /$ bcr2793

Cite this article as: Zeps $N$, Hemmings C: Chasing the immortal strand: evidence for nature's way of protecting the breast genome. Breast Cancer Research 2011, 13:101. 